\title{
A STUDY ON THE CHARACTERISTICS OF LIFE AND LIVING ENVIRONMENT OF THE ELDERLY AT THE MULTI-FAMILY HOUSES AREA IN DAEGU CITY, KOREA \\ - Comparing with the condominium area - \\ 韓国・大邱市の多家口住宅地における高齢者世帯の生活行為を支える近隣環境 \\ に関する研究 \\ 一集合住宅地との比較を通じてー
}

\begin{abstract}
Sunhwa SHIN*, Masanori SAWAKI** and Yu SHIBATA***
慎 鮮 花, 澤木昌典, 柴田 祐

This paper is to find out the actual condition of the neighborhood ${ }^{1)}$ environment which make the elderly continue to live on in that community ${ }^{\mathrm{ii})}$. The field is in the rebuilding multi-family houses area in Daegu City, Korea where many elderly person live. We discuss outdoor activities of elderly person to see the independence of their daily life and how he or she is sharing in the benefit of environment. We also discuss their reliance on networks of kinship and community relations. Especially elderly person which could be the final stage on their neighborhood relies on community relation and support of friends.
\end{abstract}

Keywords: multi-family houses area, the elderly, life activities, neighborhood environment, Korea 多家口住宅地，高齢者世帯，生活行為，近隣環境，韓国

\section{Introduction}

The multi-family houses area in large cities in Korea were established for the purpose of supply of rental houses along with the implementation of land readjustment project from 1940 to 1990 . Recently, rebuilding of the existing 2-story buildings into much bigger 4 5-story is being carried out extensively due to the aging of the housing units and aging of the population. Accordingly, moving in of the new elderly person into such the multi-family houses area has become quite active with numerous households only with single person or just married couples. Under such circumstances, the multi-family houses area, in comparison to the condominium complex, have inadequate auxiliary facilities such as rest and recreational facilities for the aged within the district, and support services for daily life by the management offices, and has limited house call care services from the administrative authorities and support for daily life by voluntary services ${ }^{1}$. For the elderly with prolonged period of time spent within the district, there is elevation in the awareness of need for support from the nearby neighborhood environment within the district for daily life activities, leisure activities and social activities, and the importance of regional residence ${ }^{\mathrm{iii}}$ ) within the district is increasing.

In particular, Korea is expected enter into the era of aged society by 2018 and increase in the proportion of the elderly in the multi-family houses area along with the redevelopment of the buildings is forecasted ${ }^{2}$. Therefore, there is a need to clarify the neighborhood environment from the daily life space and human environment that supports diverse daily life activities of elderly persons and to review the possibilities of the regional residence of elderly persons. Although there are researches on the assessment of characteristics on the use of external spaces and outing of the elderly in particular care facilities for the aged and the condominium complex as the existing researches on the relationship between the daily life activities of the elderly and the neighborhood environment in Korea, there is no research on the assessment of the relationship between the daily life activities of elderly person and the neighborhood environment with the multi-family houses area as the subjects 3) 4) 5) 6) 7)

Accordingly, this Study aims to 1)clarify the characteristics of the changes in using around the house that provides opportunity to establish neighborhood relationship and the frequency of interaction with around the house before and after moving with the elderly that moved into the neighborhood. As the subjects, 2)clarify the interaction types through the subjects, location and frequencies of interaction in the district since there is high probability that daily life activities are performed through individual interactive relationship, and 3)clarify the daily life space and human environment that support the daily life activities for each of the types of interactions with the multi-family houses area in Daegu City, one of the metropolitan cities in Korea that was developed stably without direct damages from the chaos of the Korean War as the subject. This Study further aims to disclose the characteristics of the neighborhood environment that supports the daily life activities of the elderly at the neighborhood environment and

\footnotetext{
* Graduate Student, Graduate School of Engineering, Osaka University, M. Eng.

** Prof., Graduate School of Engineering, Osaka University, Dr. Eng.

大阪大学大学院工学研究科＼cjkstart博士後期課程・工修

*** Assoc. Prof., Faculty of Environmental \& Symbiotic Sciences, Prefectural University of

大阪大学大学院工学研究科 教授.工博

Kumamoto, Dr. Eng.
} 
to obtain useful knowledge in considering the methods of consolidation of residential environment at the multi-family houses area through comparison to those of the elderly who moved into the condominium complex in the surrounding on the basis of the assessment of 1), 2) and 3) above.

\section{Overview and Survey Method for the District Subjected to Examination}

\section{1) Overview of the District Subjected to Examination}

A total of four districts, including the Land District No. 1, Land District No. 5, Suseong District and Songhyeon Districts at which rebuilding iv) is in progress, and with different location conditions and urban-foundation facilities were selected as the subject the multi-family houses area of this Study, among the land readjustment project districts in Daegu City. In addition, a total of three districts including the Boseong condominium complex, Songhyeon condominium complex and Beommul condominium complex were selected as the condominium complex in the neighborhood for the purpose of comparison with the above four districts (Fig.1., Fig.2). The above four districts of the multi-family houses area and the three districts of the condominium complex have daily life facilities including retail shops and hospital in and out of the district as well as public facilities such as resident's autonomous governance center, etc and bus station sand subways stations within walking distance. The three districts of the condominium complex have well consolidated greenery facilities, rest and recreational facilities for aged persons, and management office within the condominium complex.

\section{2) Survey Method}

A hearing survey was conducted on 31 households that moved into the redevelopment residence in the four districts of the multi-family houses area and 21 households composed of single person and married couple households that moved into the three districts of the condominium complex. The duration of the survey was from August 27 to September 15, 2010. 52 households were selected from household information of the management office and neighbor meeting in the district. Items for hearing survey included (1)the characteristics of changes in using around the house and frequency of interaction before and after moving that provided important opportunity to form neighborhood relationship, (2)location, the other party and frequency of interactions centered-around the conversation and greetings ${ }^{v}$ within the district, (3)assessment of interaction type from the location, the other party and frequency of interactions within the district, and (4)assessment of relationship between the daily life space and human environment that supports daily life activities for each of the interaction types. Through obtaining of data from the survey, comparatively analyze the characteristics of neighborhood environment that supports the daily life activities of the elderly for each of the residential types and each of the interaction types.

\section{The Characteristics of Using around the House and Characteristics of Interaction around the House and District by the Elderly for Each of the Types of Residential Areas}

Clarify the characteristics of changes in using neighborhood and the frequency of interaction including conversation and greetings in around the house before and after moving into the new district, which become important opportunity to establish neighborhood relationship, and clarify the types of the interaction from the frequency of interaction such as conversation and greeting as well as the other party of the interaction within the district. These characteristics are comparatively analyzed for each of the types of the residential areas(Table 1.).

1) The Characteristics of the Changes in Using around the House, and Frequency of Conversation and Greetings around the House Before and After the Move into the District for Each of the Types of the Residential Areas

Flower beds that were frequently visible around the house before the move have been converted into a parking lot in the multi-family houses area and the condominium complex in overall, and there are numerous residents with lowered frequency of conversation and greetings(Table 1.). Among these, the cases $2,3,4,6,8,11,13,17,18,19,21,27$ and 28 among the multi-family houses area displayed frequent use of flower bed and pedestrian walks but less conversation and greetings in comparison to other cases. These cases indicate that the characteristics of using around the house is similar even after the move if the residents lived in detached houses previously, and it is presumed that such environment is a factor the offers opportunity to have conversation and greeting.

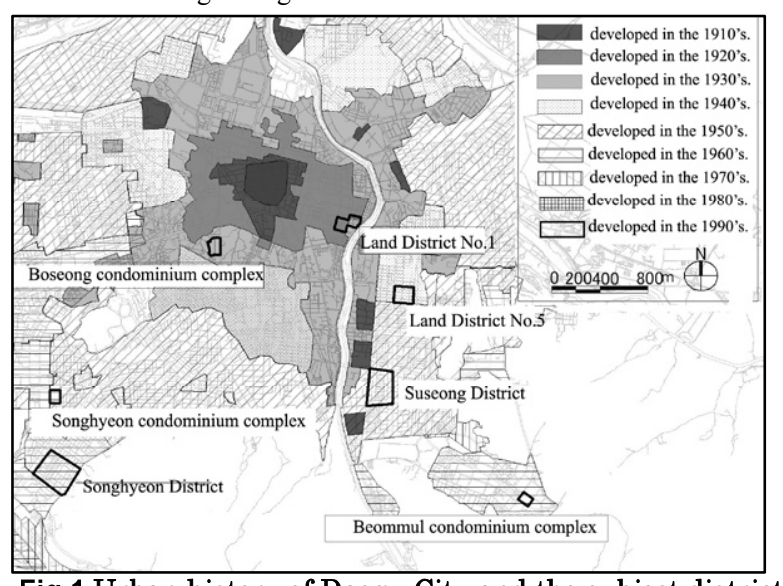

Fig.1 Urban history of Daegu City and the subject district

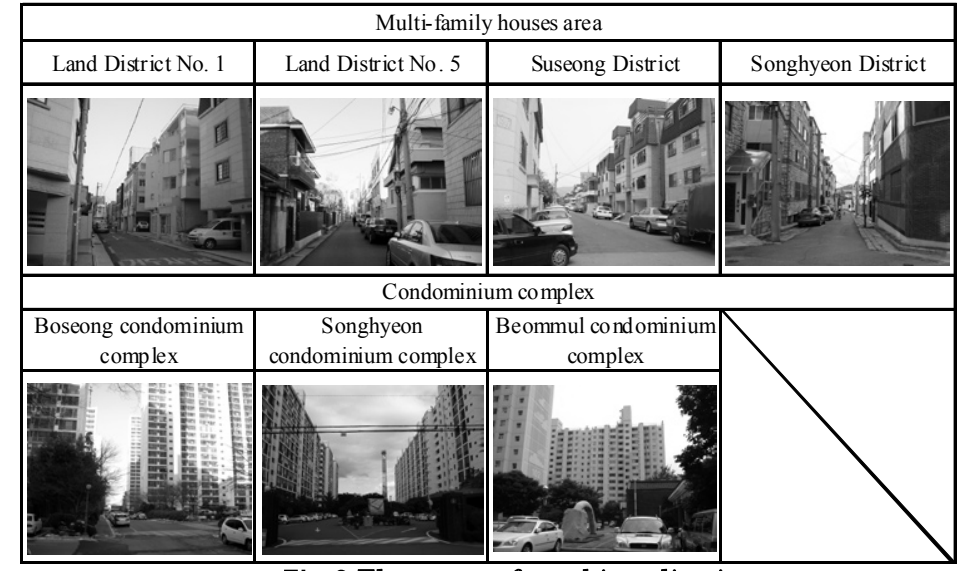

Fig.2 The scene of a subject district 
Table 1 The Characteristics of Using around the House and Characteristics of Interaction around the House and District by the Elderly

\begin{tabular}{|c|c|c|c|c|c|c|c|c|c|c|c|c|c|c|}
\hline \multirow{2}{*}{\multicolumn{2}{|c|}{ District }} & \multirow{2}{*}{$\left|\begin{array}{c}\mathrm{Ca} \\
\mathrm{se} \\
\mathrm{no}\end{array}\right| \mathrm{A}$} & \multirow{2}{*}{\multicolumn{2}{|c|}{ Age $\mid \begin{array}{l}c \\
e \\
n \\
d \\
e\end{array}$}} & \multirow[b]{2}{*}{ Household type } & \multirow{2}{*}{$\begin{array}{c}\text { House of before } \\
\text { moving into the } \\
\text { new district }\end{array}$} & \multirow{2}{*}{$\begin{array}{c}\text { Existenc } \\
\text { e of the } \\
\text { parking } \\
\text { lot of the } \\
\text { first } \\
\text { floor }\end{array}$} & \multicolumn{2}{|c|}{$\begin{array}{c}\text { The characteristics } \\
\text { of using around } \\
\text { the house }\end{array}$} & \multicolumn{2}{|c|}{$\begin{array}{c}\text { Change of frequency of } \\
\text { interaction around the } \\
\text { house for greetings and } \\
\text { conversation }\end{array}$} & \multirow{2}{*}{$\begin{array}{l}\text { Main opponent of } \\
\text { interaction within } \\
\text { and outside the } \\
\text { district for greetings } \\
\text { and conversation }\end{array}$} & \multirow{2}{*}{$\begin{array}{l}\text { Mate of } \\
\text { interaction within } \\
\text { and outside the } \\
\text { district for } \\
\text { greetings and } \\
\text { conversation }\end{array}$} & \multirow{2}{*}{$\begin{array}{l}\text { Frequency of } \\
\text { interaction } \\
\text { within and } \\
\text { outside the } \\
\text { district for } \\
\text { greetings and } \\
\text { conversation }\end{array}$} \\
\hline & & & & & & & & $\begin{array}{c}\text { Before } \\
\text { moving } \\
\text { into the } \\
\text { new } \\
\text { district }\end{array}$ & $\begin{array}{c}\text { After } \\
\text { moving } \\
\text { into the } \\
\text { new } \\
\text { district }\end{array}$ & $\begin{array}{c}\text { Before } \\
\text { moving into } \\
\text { the new } \\
\text { district }\end{array}$ & $\begin{array}{c}\text { After } \\
\text { moving into } \\
\text { the new } \\
\text { district }\end{array}$ & & & \\
\hline \multirow{31}{*}{$\begin{array}{l}\text { multi- } \\
\text { family } \\
\text { houses } \\
\text { area }\end{array}$} & \multirow{10}{*}{$\begin{array}{c}\text { Land } \\
\text { District } \\
\text { No. } 1\end{array}$} & 1 & 69 & $\mathrm{M}$ & single & $\begin{array}{c}\begin{array}{c}\text { urban-style korean } \\
\text { homse }\end{array} \\
\text { vi) }\end{array}$ & $\mathrm{O}$ & - & $\boldsymbol{\Delta}$ & $\square$ & $\square$ & public facility & group & $\square$ \\
\hline & & 2 & 72 & $\mathrm{~F}$ & single & \begin{tabular}{|c|}
$\begin{array}{c}\text { urban-style korean } \\
\text { house }\end{array}$ \\
\end{tabular} & $\mathrm{X}$ & ○ & 0 & $\square$ & $\square$ & public facility & group & $\square$ \\
\hline & & 3 & 65 & $\mathrm{~F}$ & single & detached house & $\mathrm{X}$ & $\square$ & $\Delta$ & $\square$ & $\square$ & commercial facility & $\begin{array}{c}\text { friend and } \\
\text { acquaintance }\end{array}$ & $\square$ \\
\hline & & 4 & 75 & $\mathrm{~F}$ & single & detached house & $\mathrm{X}$ & ○ & ○ & $\square$ & $\square$ & $\begin{array}{c}\begin{array}{c}\text { house of the friend } \\
\text { and acquaintance }\end{array} \\
\end{array}$ & $\begin{array}{c}\text { friend and } \\
\text { acquaintance }\end{array}$ & $\square$ \\
\hline & & 5 & 75 & $\mathrm{~F}$ & single & \begin{tabular}{|c|}
$\begin{array}{c}\text { urban-style korean } \\
\text { house }\end{array}$ \\
\end{tabular} & $\mathrm{O}$ & - & $\square$ & $\square$ & $\square$ & public facility & group & $\square$ \\
\hline & & \begin{tabular}{|l|}
6 \\
\end{tabular} & 76 & $\mathrm{M}$ & single & detached house & $\mathrm{X}$ & $\Delta$ & $\Delta$ & $\square$ & $\square$ & public facility & group & $\square$ \\
\hline & & 7 & 74 & $\mathrm{~F}$ & husband and wife & detached house & $\mathrm{O}$ & $\square$ & $\square$ & $\square$ & $\square$ & $\begin{array}{c}\text { inside and outside } \\
\text { of a house }\end{array}$ & relative & $\square$ \\
\hline & & 8 & 66 & $\mathrm{~F}$ & husband and wife & detached house & $\mathrm{X}$ & $\boldsymbol{\Delta}$ & ○ & $\square$ & $\square$ & $\begin{array}{c}\text { house of the friend } \\
\text { and acquaintance } \\
\text { outside the district }\end{array}$ & $\begin{array}{l}\text { friend and } \\
\text { acquaintance }\end{array}$ & 口ص \\
\hline & & 9 & 66 & $\mathrm{~F}$ & husband and wife & multi-family house & O & O & $\square$ & $\square$ & $\square \square$ & \begin{tabular}{|c|} 
house of the \\
children and relative \\
outside the district
\end{tabular} & children & $\square$ \\
\hline & & 10 & 66 & $\mathrm{~F}$ & husband and wife & multi-family house & $\mathrm{O}$ & $\boldsymbol{\Delta}$ & $\square$ & $\square$ & $\square$ & $\begin{array}{c}\text { inside and outside } \\
\text { of a house }\end{array}$ & children & $\square$ \\
\hline & \multirow{6}{*}{$\begin{array}{c}\text { Land } \\
\text { District } \\
\text { No. } 5\end{array}$} & 11 & 75 & $\mathrm{~F}$ & single & detached house & $X$ & - & $\boldsymbol{\Delta}$ & $\square$ & $\square$ & $\begin{array}{c}\text { house of the friend } \\
\text { and acquaintance }\end{array}$ & $\begin{array}{c}\text { friend and } \\
\text { acquaintance }\end{array}$ & $\square \square$ \\
\hline & & 12 & 76 & $\mathrm{M}$ & single & multi-family house & $\mathrm{O}$ & $\Delta$ & $\square$ & $\square$ & $\square$ & public facility & group & $\square$ \\
\hline & & 13 & 75 & $\mathrm{~F}$ & single & multi-family house & $\mathrm{X}$ & ○ & ○ & $\square$ & $\square$ & commercial facility & $\begin{array}{c}\text { friend and } \\
\text { acquaintance }\end{array}$ & $\square$ \\
\hline & & 14 & 67 & $\mathrm{~F}$ & single & multi-family house & $\mathrm{O}$ & $\boldsymbol{\Delta}$ & $\square$ & $\square$ & $\square$ & $\begin{array}{c}\text { inside and outside } \\
\text { of a house }\end{array}$ & children & $\square$ \\
\hline & & 15 & 76 & $\mathrm{~F}$ & husband and wife & multi-family house & $\mathrm{O}$ & $\square$ & $\square$ & $\square$ & $\square$ & $\begin{array}{c}\text { inside and outside } \\
\text { of a house }\end{array}$ & children & 미 \\
\hline & & 16 & 75 & $\mathrm{~F}$ & single & multi-family house & O & $\boldsymbol{\Delta}$ & $\boldsymbol{\Delta}$ & $\square$ & $\square \square$ & $\begin{array}{c}\text { house of the } \\
\text { children and relative } \\
\text { outside the district }\end{array}$ & children & $\square$ \\
\hline & \multirow{9}{*}{$\begin{array}{c}\text { Su- } \\
\text { seong } \\
\text { District }\end{array}$} & 17 & 66 & $\mathrm{~F}$ & single & detached house & $\mathrm{X}$ & ○ & ○ & $\square$ & $\square$ & $\begin{array}{c}\text { house of the friend } \\
\text { and acquaintance }\end{array}$ & $\begin{array}{c}\text { friend and } \\
\text { acquaintance }\end{array}$ & $\square$ \\
\hline & & 18 & 77 & $\mathrm{M}$ & single & multi-family house & $\mathrm{X}$ & $\Delta$ & 0 & $\square$ & $\square$ & public facility & group & $\square$ \\
\hline & & 19 & 75 & $\mathrm{M}$ & single & multi-family house & $X$ & - & 0 & $\square$ & $\square$ & $\begin{array}{l}\text { house of the friend } \\
\text { and acquaintance }\end{array}$ & $\begin{array}{c}\text { friend and } \\
\text { acquaintance }\end{array}$ & $\square$ \\
\hline & & 20 & 72 & $\mathrm{~F}$ & single & detached house & $\mathrm{O}$ & - & $\square$ & $\square$ & $\square$ & $\begin{array}{l}\text { house of the friend } \\
\text { and acquaintance }\end{array}$ & $\begin{array}{c}\text { friend and } \\
\text { acquaintance }\end{array}$ & $\square$ \\
\hline & & 21 & 70 & $\mathrm{M}$ & single & multi-family house & $\mathrm{X}$ & $\Delta$ & 0 & $\square$ & $\square$ & public facility & group & $\square$ \\
\hline & & 22 & 69 & $\mathrm{M}$ & husband and wife & multi-family house & $\mathrm{O}$ & $\boldsymbol{\Delta}$ & $\square$ & $\square$ & $\square$ & $\begin{array}{c}\text { house of the friend } \\
\text { and acquaintance } \\
\text { outside district }\end{array}$ & $\begin{array}{l}\text { friend and } \\
\text { acquaintance }\end{array}$ & $\square$ \\
\hline & & 23 & 71 & $\mathrm{~F}$ & husband and wife & detached house & $\mathrm{O}$ & $\square$ & $\square$ & $\square$ & $\square \square$ & $\begin{array}{c}\text { house of the } \\
\text { children and relative } \\
\text { outside the district }\end{array}$ & children & $\square$ \\
\hline & & 24 & 78 & $\mathrm{M}$ & single & $\begin{array}{l}\text { condominium } \\
\text { comple }\end{array}$ & $\mathrm{O}$ & $\square$ & $\square$ & $\square$ & $\square$ & $\begin{array}{c}\text { inside and outside of } \\
\text { a house }\end{array}$ & relative & $\square$ \\
\hline & & 25 & 74 & $\mathrm{~F}$ & husband and wife & $\begin{array}{c}\text { condominium } \\
\text { comple }\end{array}$ & $\mathrm{O}$ & 0 & $\square$ & $\square$ & $\square$ & $\begin{array}{c}\text { inside and outside of } \\
\text { a house }\end{array}$ & children & $\square$ \\
\hline & \multirow{6}{*}{\begin{tabular}{|c|} 
Song- \\
hyeon \\
District
\end{tabular}} & 26 & 76 & $\mathrm{M}$ & husband and wife & multi-family house & $\mathrm{O}$ & $\boldsymbol{\Delta}$ & $\square$ & $\square$ & $\square$ & $\begin{array}{c}\text { commercial facility } \\
\text { outside the area }\end{array}$ & $\begin{array}{c}\text { friend and } \\
\text { acquaintance }\end{array}$ & $\square$ \\
\hline & & 27 & 75 & $\mathrm{~F}$ & husband and wife & multi-family house & $\mathrm{X}$ & 0 & $\boldsymbol{\Delta}$ & $\square$ & $\square$ & $\begin{array}{c}\text { commercial facility } \\
\text { outside the area }\end{array}$ & group & $\square$ \\
\hline & & 28 & 71 & $\mathrm{~F}$ & single & detached house & $\mathrm{X}$ & 0 & - & $\square$ & $\square$ & commercial facility & $\begin{array}{c}\text { friend and } \\
\text { acquaintance }\end{array}$ & $\square$ \\
\hline & & 29 & 79 & $\mathrm{~F}$ & husband and wife & multi-family house & $\mathrm{O}$ & $\boldsymbol{\Delta}$ & $\square$ & $\square$ & $\square$ & \begin{tabular}{|c|} 
house of the \\
children and relative \\
outside the district
\end{tabular} & children & $\square$ \\
\hline & & 30 & 75 & $\mathrm{~F}$ & single & multi-family house & $\mathrm{O}$ & • & $\square$ & $\square$ & $\square$ & $\begin{array}{c}\text { inside and outside } \\
\text { of a house }\end{array}$ & children & $\square$ \\
\hline & & 31 & 76 & $\mathrm{~F}$ & husband and wife & multi-family house & $\mathrm{O}$ & $\square$ & $\square$ & $\square$ & $\square$ & $\begin{array}{c}\text { inside and outside of } \\
\text { a house }\end{array}$ & children & $\square$ \\
\hline \multirow{3}{*}{$\begin{array}{c}\text { condom } \\
\text { inium } \\
\text { comple } \\
\mathrm{x}\end{array}$} & \multirow{3}{*}{$\left|\begin{array}{c}\text { Bo- } \\
\text { seong } \\
\text { condomi } \\
\text { nium } \\
\text { complex }\end{array}\right|$} & 32 & 76 & $\mathrm{~F}$ & single & detached house & - & 0 & $\square$ & $\square$ & $\square$ & $\begin{array}{c}\text { inside and outside } \\
\text { of a house }\end{array}$ & children & $\square$ \\
\hline & & 33 & 65 & $\mathrm{M}$ & single & detached house & 二 & 0 & $\Delta$ & $\square$ & $\square$ & $\begin{array}{c}\text { commercial facility } \\
\text { outside the area }\end{array}$ & group & $\square$ \\
\hline & & 34 & 77 & $\mathrm{M}$ & single & multi-family house & - & $\boldsymbol{\Delta}$ & $\square$ & $\square$ & $\square$ & $\begin{array}{c}\text { commercial facility } \\
\text { outside the area }\end{array}$ & $\begin{array}{l}\text { friend and } \\
\text { acauaintance }\end{array}$ & $\square$ \\
\hline
\end{tabular}




\begin{tabular}{|c|c|c|c|c|c|c|c|c|c|c|c|c|c|}
\hline & 35 & 66 & $\mathrm{M}$ & single & $\begin{array}{c}\text { urban-style korean } \\
\text { house }\end{array}$ & - & $\bullet$ & $\square$ & $\square$ & $\square$ & $\begin{array}{c}\text { the house of the } \\
\text { children and relative } \\
\text { outside the district }\end{array}$ & children & $\square$ \\
\hline & 36 & 65 & $F$ & husband and wife & $\begin{array}{c}\text { urban-style korean } \\
\text { house }\end{array}$ & - & 0 & $\Delta$ & $\square$ & $\square$ & $\begin{array}{l}\text { house of the friend } \\
\text { and acquaintance } \\
\text { outside the district }\end{array}$ & $\begin{array}{c}\text { friend and } \\
\text { acquaintance }\end{array}$ & $\square$ \\
\hline & 37 & 75 & $\mathrm{M}$ & husband and wife & detached house & - & $\Delta$ & $\square$ & $\square$ & $\square$ & public facility & group & $\square$ \\
\hline & 38 & 70 & $\mathrm{~F}$ & husband and wife & detached house & - & $\Delta$ & $\square$ & $\square$ & $\square$ & $\begin{array}{c}\text { house of the } \\
\text { children and relative } \\
\text { outside the district }\end{array}$ & children & $\square$ \\
\hline \multirow{7}{*}{$\begin{array}{c}\text { Song- } \\
\text { hyeon } \\
\text { condomi } \\
\text { nium } \\
\text { complex }\end{array}$} & 39 & 66 & $\mathrm{~F}$ & single & detached house & - & $\Delta$ & $\Delta$ & $\square$ & $\square$ & commercial facility & $\begin{array}{c}\text { friend and } \\
\text { acguaintance }\end{array}$ & $\square$ \\
\hline & 40 & 75 & $\mathrm{M}$ & single & multi-family house & - & $\Delta$ & $\square$ & $\square$ & $\square$ & public facility & group & $\square$ \\
\hline & 41 & 69 & $\mathrm{M}$ & single & $\begin{array}{c}\text { urban-style korean } \\
\text { house }\end{array}$ & - & - & $\boldsymbol{\Delta}$ & $\square$ & $\square$ & \begin{tabular}{|c|} 
house of the \\
children and relative \\
outside the district
\end{tabular} & children & $\square$ \\
\hline & 42 & 66 & $\mathrm{M}$ & husband and wife & detached house & - & $\square$ & $\boldsymbol{\Delta}$ & $\square$ & $\square$ & $\begin{array}{c}\text { commercial facility } \\
\text { outside the area }\end{array}$ & group & $\square$ \\
\hline & 43 & 74 & $F$ & husband and wife & multi-family house & - & $\square$ & $\Delta$ & $\square$ & $\square$ & $\begin{array}{c}\text { house of the } \\
\text { children and relative } \\
\text { outside the district }\end{array}$ & children & $\square$ \\
\hline & 44 & 76 & $\mathrm{M}$ & single & multi-family house & - & - & $\square$ & ( & $\square$ & $\begin{array}{c}\text { inside and outside } \\
\text { of a house }\end{array}$ & relative & $\square$ \\
\hline & 45 & 75 & $\mathrm{~F}$ & single & multi-family house & - & 0 & $\square$ & $\square$ & $\square$ & $\begin{array}{c}\text { inside and outside } \\
\text { of a house }\end{array}$ & children & $\square$ \\
\hline \multirow{7}{*}{$\begin{array}{c}\text { Beom- } \\
\text { mul } \\
\text { condomi } \\
\text { nium } \\
\text { complex }\end{array}$} & 46 & 76 & $\mathrm{~F}$ & single & multi-family house & - & - & $\square$ & $\square$ & $\square$ & $\begin{array}{c}\text { inside and outside } \\
\text { of a house }\end{array}$ & children & प्य \\
\hline & 47 & 72 & $\mathrm{~F}$ & single & multi-family house & - & - & $\Delta$ & $\square$ & $\square$ & commercial facility & group & $\square$ \\
\hline & 48 & 75 & $\mathrm{M}$ & single & detached house & - & - & $\boldsymbol{\Delta}$ & $\square$ & $\square$ & $\begin{array}{c}\text { inside and outside } \\
\text { of a house }\end{array}$ & children & $\square$ \\
\hline & 49 & 66 & $\mathrm{M}$ & single & detached house & - & $\Delta$ & $\boldsymbol{\Delta}$ & $\square$ & $\square$ & $\begin{array}{l}\text { house of the friend } \\
\text { and acquaintance } \\
\text { outside the district }\end{array}$ & $\begin{array}{c}\text { friend and } \\
\text { acquaintance }\end{array}$ & $\square$ \\
\hline & 50 & 75 & $\mathrm{M}$ & single & multi-family house & - & $\Delta$ & $\square$ & $\square$ & $\square$ & $\begin{array}{c}\text { inside and outside } \\
\text { of a house }\end{array}$ & relative & $\square$ \\
\hline & 51 & 77 & $\mathrm{M}$ & single & multi-family house & - & $\Delta$ & $\boldsymbol{\Delta}$ & $\square$ & $\square$ & $\begin{array}{c}\text { inside and outside } \\
\text { of a house }\end{array}$ & children & $\square$ \\
\hline & 52 & 71 & $\mathrm{~F}$ & husband and wife & multi-family house & - & $\square$ & $\square$ & $\square$ & एव & commercial facility & $\begin{array}{c}\text { friend and } \\
\text { acquaintance }\end{array}$ & प्य \\
\hline
\end{tabular}

2) The Characteristics of the Location, the Other Party and Frequencies of the Interaction in District for Each of the Types of the Residential Areas

Examination of the characteristics of the location, the other party and frequencies of the interaction such as conversation and greetings within the district displays that (Table 1.), in particular, for cases 2, 3, 4, 6, 13, 17, 18, 19, 21, 24 and 28 with high frequency of conversation and greetings around the house in the multi-family houses area, the location of interaction most includes residence of friend and acquaintances in the vicinity, commercial facilities such as retail outlet and public facilities such as resident's center within the district, while the majority of the other party of the interaction was friends, acquaintances and members of groups ${ }^{\mathrm{vii}}$. For the cases $33,34,35,36,38,41,42,43$ and 48 for the condominium complex, the location of interaction was mostly at the residence of children, friend and acquaintances, and commercial facilities outside the district with limited parties of the interaction that included only children living separately, friends and acquaintances. Based on these findings, commercial facilities such as retail outlets in the vicinity within the district are being used as a location of interaction such as conversation and greetings by the elderly in the multi-family houses area, thereby providing opportunity for interaction within the district.

\section{The Characteristics of Neighborhood Environment that Supports the Daily Life Activities of the Elderly Viewed from the Cases Each of the Types of Residence and Interaction}

Daily life of elderly persons within the district is classified according to the five interaction types including individual relationship type, group activity type, regional external type, relatives type and non-interactive type on the basis of the location, the other party and frequency of the interaction, with the presumption that it is conducted along with interactive relationship with the surrounding(Table 1., Table 2., Fig.3., Fig.4.). In addition, the relationship between the interaction type with the types of household and age was assessed since the interaction types vary in accordance with the changes in the household type and age. The scope of the daily life space that enables the elderly to pursue daily life activities within the regions and the characteristics of neighborhood environment are comparatively analyzed on the basis of the human environment including the children, friends and acquaintances that support the daily life activities for each of the interaction types.

1) The Characteristics of interaction types, and relationship with the household type and age for each of the types of the residential areas

There are more individual relationship type and group activity type, regional external type and relatives type in the multi-family houses area, while the condominium complex is characterized by more group activity type, regional external type and non-interactive type, etc(Table 2.). In addition, examination of the relationship with the household types and age illustrate that, in the multi-family houses area, cases 4,11,13 and 19 were individual 
relationship type, and cases 5, 6,12 and 18 were group activity type with a large number of single-elderly household, while in the condominium complex, cases 44 and 50 were relatives type, and cases $45,46,48$ and 51 were non-interactive type with large number of single-elderly household. In the multi-family houses area, it was possible to as certain that there is close relationship between the people and environment in the neighborhood within the district through individual relationship and group activities even if the scope of activities due to aging and segregation of households becomes narrower.

2) The Characteristics of Daily Life Space and Human Environment that Supports the Daily Life Activities of the Elderly Viewed from the Cases for Each of the Residence Types and Interaction Types

(1) Individual relationship type: The scope of daily life space of the case 4 of the multi-family houses area is the neighborhood in cluding the house, and leads basic daily life including having meals by mutually visiting the house of friends within the district $2 \sim 3$ times a week. There is wide range of static activities through greetings and conversation with acquaintances met around the house and through rest. There are human support including preparation of meals and confirmation of well-being through visit by children living separately and the neighbors about once a week, and receiving assistance from the neighbors in the event of occurrence of emergency situations. In contrast, the case 32 in the condominium complex has the scope of daily life space centered-around the house, and is receiving support for basic daily life through the visits from children living separately $2 \sim 3$ times a week. There is no mutual support from the neighbors (Table 3., Fig.4.).

(2) Group activity type: In case 18 in the multi-family houses area, the scope of daily life space the neighborhood including the house, and daily life is composed mainly of static activities, social activities and leisure activities 2 3 times a week at public facilities such as senior citizen's center $^{\text {viii) }}$, resident's center ${ }^{\text {ix) }}$ and commercial facilities within the district. Friends and acquaintances within the district who participate in the same group activities are visiting about once a week to verify well-being and for outing. In addition, mutual support with those belonging to the same group is very active in the event of emergency situations. However, there is high probability that the mutual support may decline if the members of the group activities change. In contrast, the scope of daily life space of the case 40 in the condominium complex daily life space is outside the district with extensive social activities and leisure activities of approximately $2 \sim 3$ times a week at commercial facilities such as retail outlets outside the district. Support for basic daily life is given only through the visit by children living separately outside the district about once a week.

(3) Regional and external type: The scope of daily life space of the case 16 in the multi-family houses area and case 34 in the condominium complex is outside the district, with fundamental daily life activities, social activities and leisure activities being performed at public and commercial facilities outside the district 2 3 times a week. Wide range of locations throughout the entire city is being used. However, in case 16 in the multi-family houses area, commercial facilities such as retail outlets

\begin{tabular}{|c|c|c|}
\hline Interaction type & Diagram & Explanation \\
\hline $\begin{array}{l}\text { Individual } \\
\text { relationship type }\end{array}$ & & $\begin{array}{l}\text { establishment of relationship through } \\
\text { mutual visit to the house of friends }\end{array}$ \\
\hline Group activity type & & $\begin{array}{l}\text { interaction and making friends through } \\
\text { group activities }\end{array}$ \\
\hline $\begin{array}{l}\text { Regional and } \\
\text { external type }\end{array}$ & & $\begin{array}{l}\text { have broad range of interactions and } \\
\text { multiple number of interactive } \\
\text { environment }\end{array}$ \\
\hline Relatives type & & $\begin{array}{l}\text { interaction centered-around the visits } \\
\text { by relatives and children with little } \\
\text { interaction within the district }\end{array}$ \\
\hline Non-interactive type & & $\begin{array}{l}\text { there is almost no interaction and } \\
\text { almost no visit by relatives and } \\
\text { children }\end{array}$ \\
\hline individual & & $\begin{array}{l}\text { house of friends and } \\
\text { other facilities for } \\
\text { interaction }\end{array}$ \\
\hline
\end{tabular}

Fig. 3 Classification of Interaction Type

Table 2 The Characteristics of interaction types, and relationship with the household type and age for each of the types of the residential areas

\begin{tabular}{|c|c|c|c|c|c|c|c|}
\hline \multicolumn{2}{|c|}{$\begin{array}{c}\text { Types of residential } \\
\text { area }\end{array}$} & $\begin{array}{c}\text { Househol } \\
\mathrm{d} \text { type }\end{array}$ & $\begin{array}{c}\text { Individual } \\
\text { relationship } \\
\text { type }\end{array}$ & $\begin{array}{c}\text { Group } \\
\text { activity type }\end{array}$ & $\begin{array}{l}\text { Regional and } \\
\text { external type }\end{array}$ & $\begin{array}{c}\text { Relative } \\
\text { s type }\end{array}$ & \begin{tabular}{|c|} 
Non- \\
interactiv \\
e type \\
\end{tabular} \\
\hline \multirow{8}{*}{$\begin{array}{c}\text { Multi- } \\
\text { family } \\
\text { houses } \\
\text { area }\end{array}$} & \multirow{2}{*}{\begin{tabular}{|c} 
Land \\
District No. \\
1
\end{tabular}} & single & $3(65), 4(75)$ & $\begin{array}{l}1(69), 2(72), \\
5(75), 6(76)\end{array}$ & - & - & - \\
\hline & & $\begin{array}{l}\text { husband } \\
\text { and wife }\end{array}$ & - & $8(66)$ & $9(66)$ & 7(74) & $10(66)$ \\
\hline & \multirow{2}{*}{\begin{tabular}{|c|} 
Land \\
District No. \\
5
\end{tabular}} & single & $11(75), 13(75)$ & $12(76)$ & $16(75)$ & - & $14(67)$ \\
\hline & & \begin{tabular}{|l} 
husband \\
and wife
\end{tabular} & - & - & - & - & $15(76)$ \\
\hline & \multirow{2}{*}{$\begin{array}{l}\text { Suseong } \\
\text { District }\end{array}$} & single & \begin{tabular}{|l|}
$17(66), 19(75)$ \\
$20(72)$
\end{tabular} & \begin{tabular}{|l|}
$18(77)$, \\
$21(70)$ \\
\end{tabular} & - & $24(78)$ & - \\
\hline & & \begin{tabular}{|l|} 
husband \\
and wife
\end{tabular} & - & - & $22(69), 23(71)$ & - & $25(74)$ \\
\hline & \multirow{2}{*}{$\begin{array}{l}\text { Songhyeon } \\
\text { District }\end{array}$} & single & $28(71)$ & - & - & - & $30(75)$ \\
\hline & & \begin{tabular}{|l} 
husband \\
and wife
\end{tabular} & - & - & $\begin{array}{l}26(76), 27(75), \\
29(79)\end{array}$ & - & $31(76)$ \\
\hline \multirow{6}{*}{$\begin{array}{c}\text { Condo- } \\
\text { miniu } \\
\mathrm{m} \\
\text { comple }\end{array}$} & \multirow{2}{*}{$\begin{array}{c}\text { Boseong } \\
\text { cond ominiu } \\
\text { m complex }\end{array}$} & single & $32(76)$ & - & \begin{tabular}{|l}
$33(65), 34(77)$, \\
$35(66)$
\end{tabular} & - & - \\
\hline & & $\begin{array}{l}\text { husband } \\
\text { and wife }\end{array}$ & - & $37(75)$ & $36(65), 38(70)$ & - & - \\
\hline & \multirow{2}{*}{$\begin{array}{c}\text { Songhyeon } \\
\text { cond ominiu } \\
\text { m complex }\end{array}$} & single & $39(66)$ & $40(75)$ & $41(69)$ & $44(76)$ & $45(75)$ \\
\hline & & \begin{tabular}{|l|} 
husband \\
and wife \\
\end{tabular} & - & - & $42(66), 43(74)$ & - & - \\
\hline & \multirow{2}{*}{$\begin{array}{c}\text { Beommul } \\
\text { cond ominiu } \\
\text { m complex }\end{array}$} & single & - & $47(72)$ & $49(66)$ & $50(75)$ & $\begin{array}{l}46(76), \\
48(75), \\
51(77)\end{array}$ \\
\hline & & \begin{tabular}{|l|} 
husband \\
and wife
\end{tabular} & $52(71)$ & - & - & - & - \\
\hline
\end{tabular}

Table 3 Classification of Daily Life Activities

\begin{tabular}{|c|c|l|}
\hline Major category & Intermediate category & \multicolumn{1}{|c|}{ Detailed category } \\
\hline \multirow{4}{*}{$\begin{array}{c}\text { Basic daily life } \\
\text { activities }\end{array}$} & sleeping & sleeping \\
\cline { 2 - 3 } & having meals & having meals \\
\cline { 2 - 3 } & bathing & bathing \\
\cline { 2 - 3 } & visit hospital & visit hospital, , medical examination \\
\cline { 2 - 3 } & household chores & laundry, cleaning, preparing meals \\
\hline Static activities & static & radio, newspaper, rest, conversation \\
\hline \multirow{4}{*}{ Social activities } & purchasing of goods & purchasing of goods \\
\cline { 2 - 3 } & work & work, part time \\
\cline { 2 - 3 } & participate in social activities & voluntary service activities \\
\hline \multirow{4}{*}{$\begin{array}{c}\text { Leisure } \\
\text { activities }\end{array}$} & hobbies & music, horticulture, handicraft, creation \\
\cline { 2 - 3 } & exercise & stretching, vacation, swimming, dance \\
\cline { 2 - 3 } & strolling & strolling \\
\cline { 2 - 3 } & viewing scenery & shopping, movies, museum, lectures, \\
& singing & singing, chess, baduk \\
\cline { 2 - 3 } & &
\end{tabular}


Multi-family houses area Relation between the life space and life activities Relation between the life space and human environment

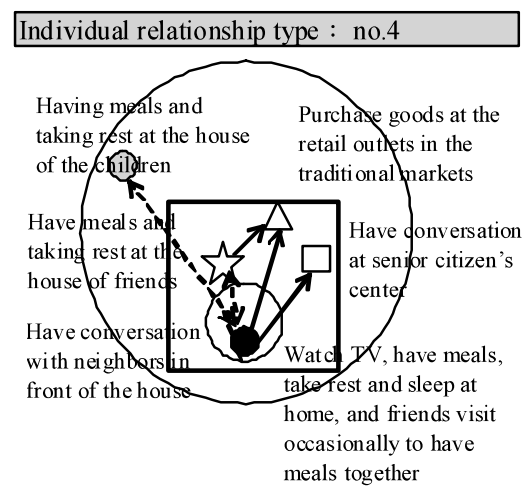

\begin{tabular}{|c|c|c|c|c|}
\hline \multirow{2}{*}{$\underbrace{\begin{array}{r}\text { Daily } \\
\text { life } \\
\text { activities }\end{array}}_{\text {Daily liff }}$} & $\begin{array}{c}\text { Basic } \\
\text { daily life } \\
\text { activities }\end{array}$ & $\begin{array}{c}\text { Static } \\
\text { activities }\end{array}$ & $\begin{array}{c}\text { Social } \\
\text { activities }\end{array}$ & $\begin{array}{c}\text { Leisure } \\
\text { activities }\end{array}$ \\
\hline & $\begin{array}{c}\text { sleeping, } \\
\text { having } \\
\text { meals }\end{array}$ & $\begin{array}{l}\text { radio, } \\
\text { rest, } \\
\text { conver- } \\
\text { sation }\end{array}$ & $\begin{array}{l}\text { purchasin } \\
\text { g of } \\
\text { goods, } \\
\text { visit } \\
\text { hospital }\end{array}$ & $\begin{array}{l}\text { hobbies, } \\
\text { strolling, } \\
\text { exercise }\end{array}$ \\
\hline $\begin{array}{c}\text { Inside of } \\
\text { house }\end{array}$ & & & & \\
\hline $\begin{array}{c}\text { Outside of } \\
\text { house }\end{array}$ & & & & \\
\hline $\begin{array}{l}\text { House of the } \\
\text { friend and } \\
\text { acquaintance }\end{array}$ & & & & \\
\hline $\begin{array}{l}\text { Public } \\
\text { facility }\end{array}$ & & & & \\
\hline \begin{tabular}{|c} 
Commercial \\
facility
\end{tabular} & & & & \\
\hline $\begin{array}{c}\text { Out side the } \\
\text { district }\end{array}$ & & & & \\
\hline
\end{tabular}

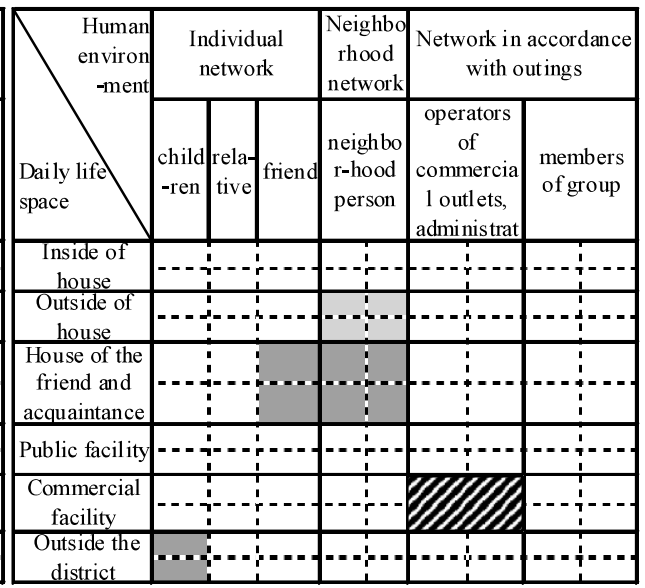

Children living separately visits the house about once a week to prepare meals. They purchase goods about once a week with acquaintances in the vicinity, and visit public bath and hos pital. Occasionally they request friends to purchase goods for them. In addition, although they visit the senior citizen's center and resident's center, they do not stay for long if the number of acquaint ances at the center is small
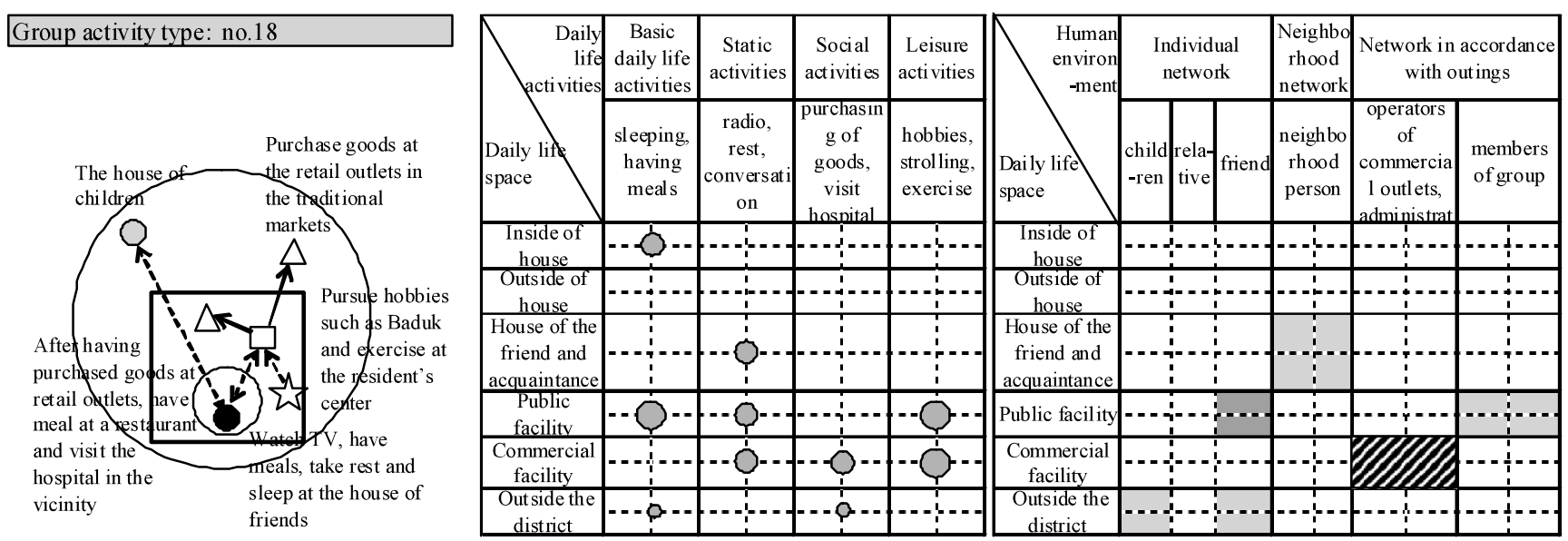

Children living separately visit the house about once a month to prepare meals and to check their well-being. In addition, they participate in hobby meeting $2 \sim 3$ times a week at the senior citizen's center and resident's center within the district. If this is difficult, they visit the house of those they got to know at the meeting or purchase goods at retail outlets within the district or visit hospital together.
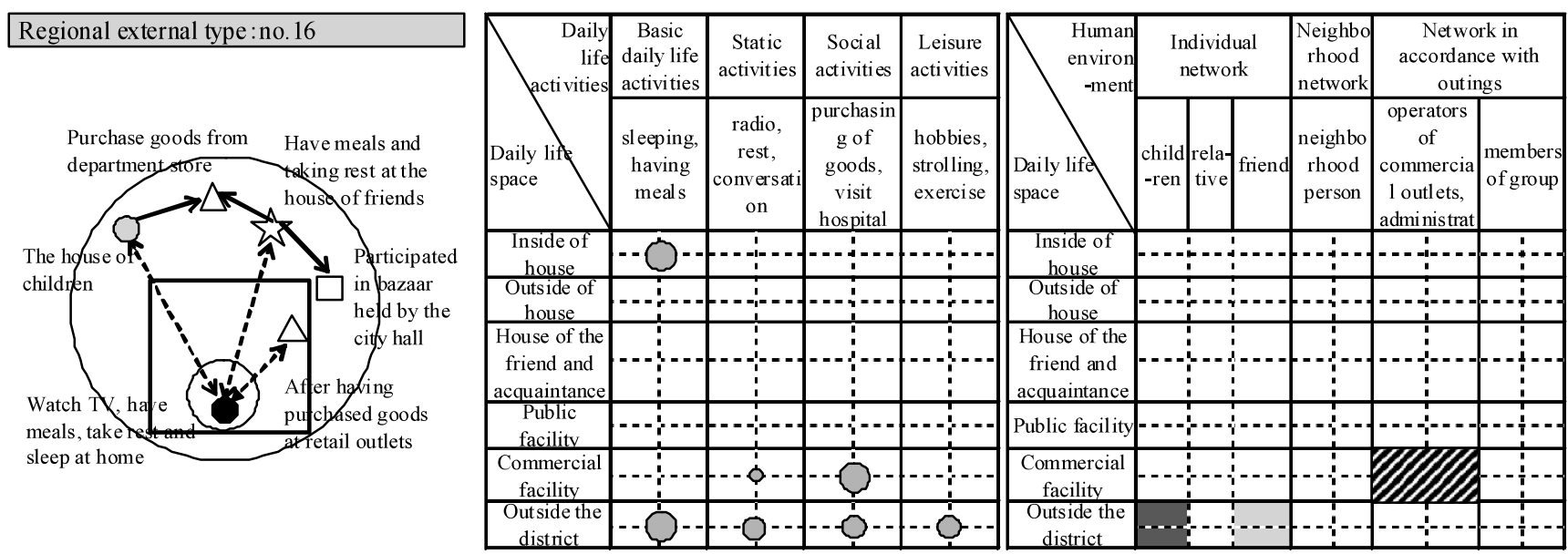

Children living separately and friends within the district visit the house $2 \sim 3$ times a month to have meal and convers ation together. In addition, they purchase goods at department stores in the surrounding or visit hospital together. In addition, they purchase goods at retail outlets within the district. 

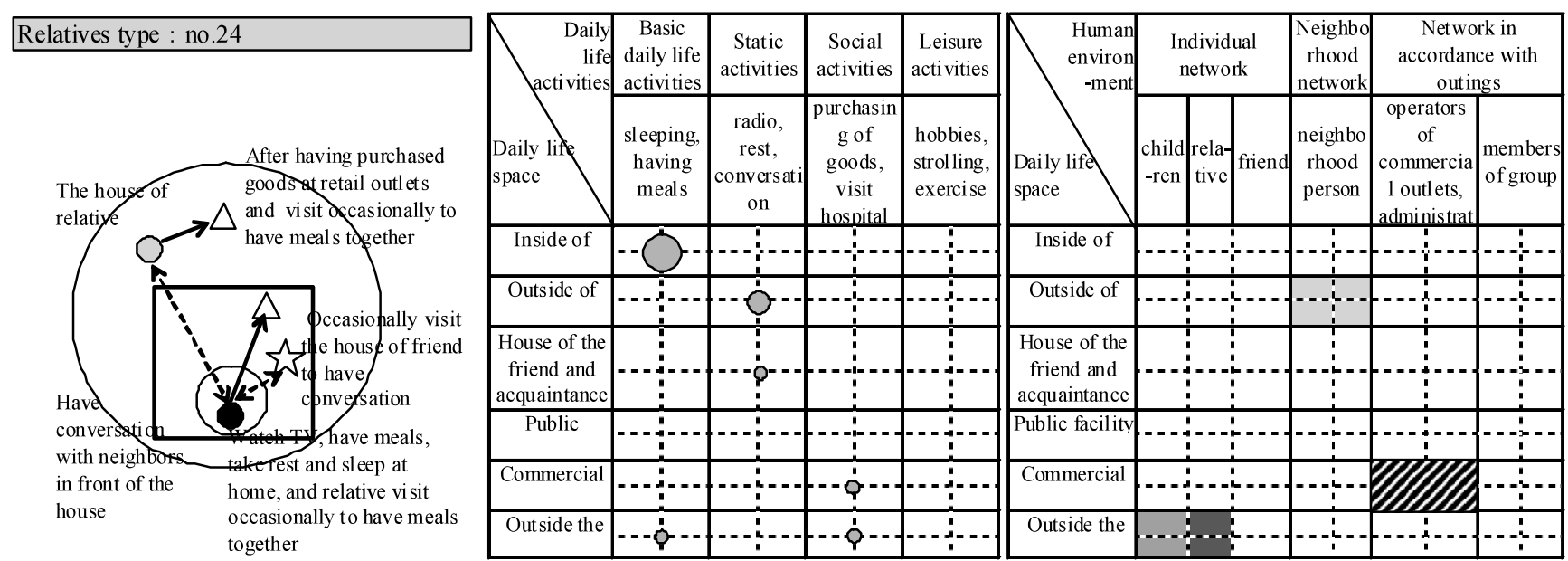

Children living separately and close relative visit the house $2 \sim 3$ times a week to prepare meals and to check their well-being. In addition, hospitals in the vicinity of the house of the children living separately are used for medical services. In addition, they request the neighbors in the vicinity to purchase goods for them.
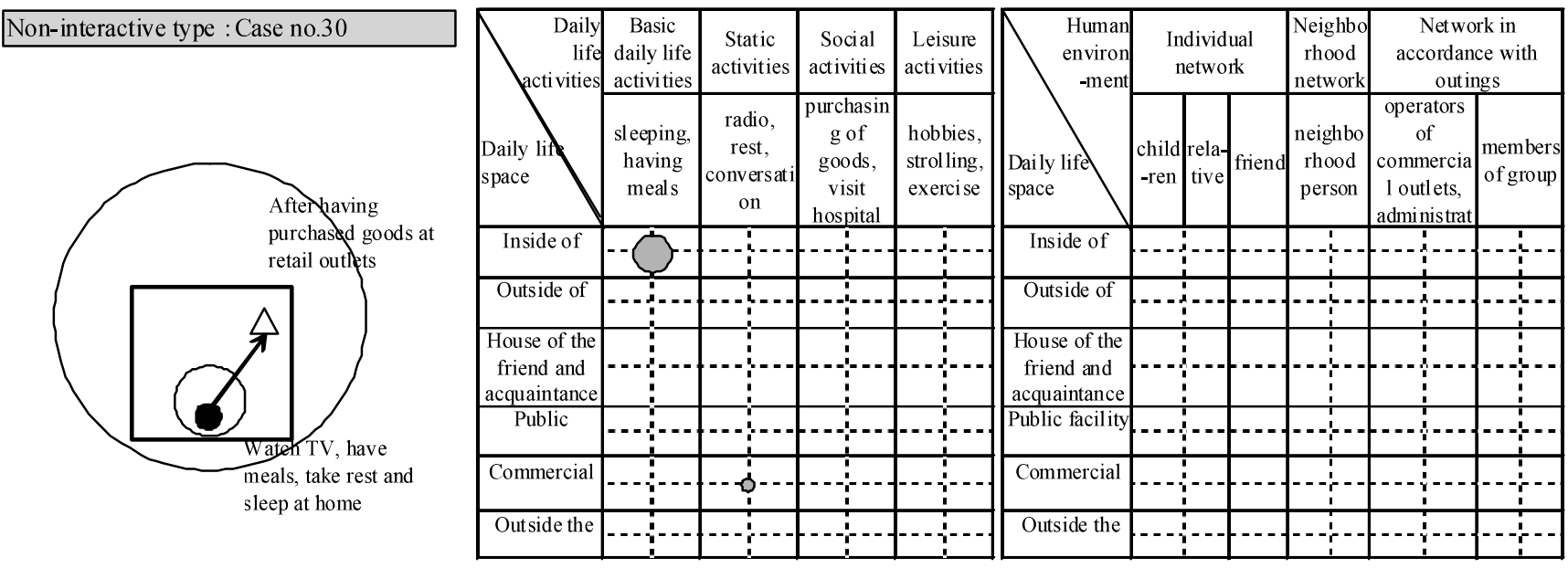

Although they have children living separately, they perform basic daily life activities such as having meals on they own at home. Even though they may have stroll at a park within the district, they do not have conversation with others. In addition, even though they purchase goods at retail outlets, they only share greetings when they encounter neighbors in the vicinity in front of the retail shop.

Condominium complex

Relation between the life space and life activities Relation between the life space and human environment
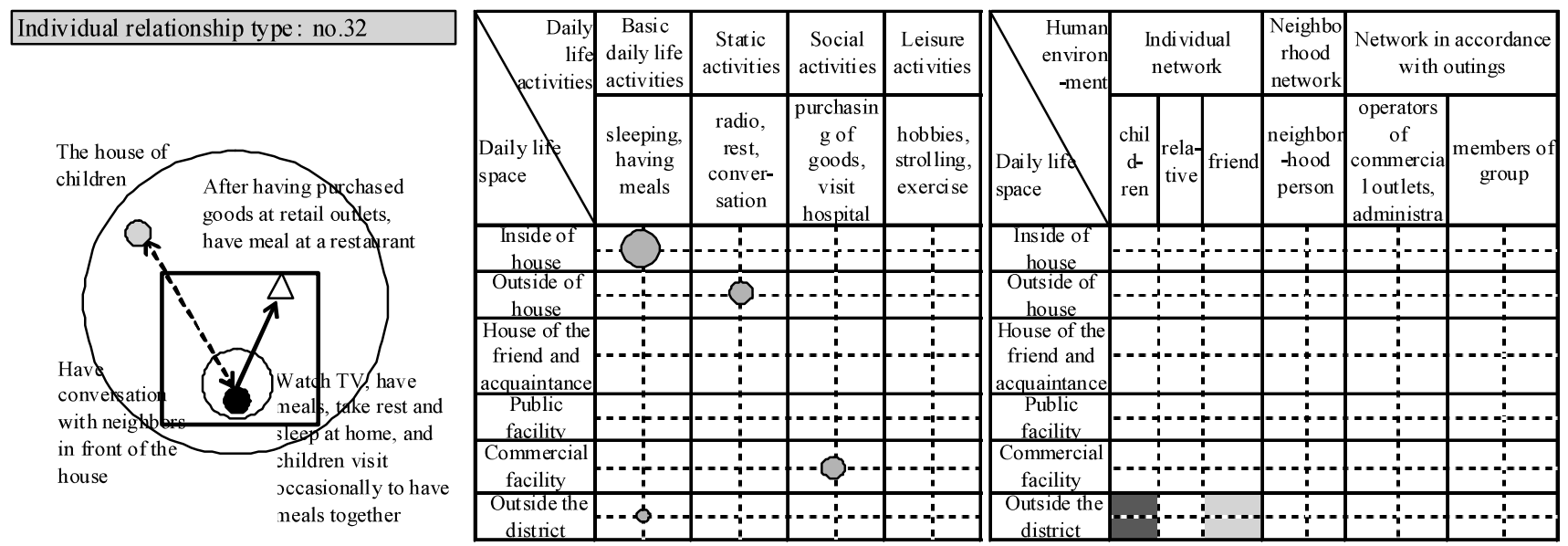

Children living separat ely visit the house about once a week to prepare meals. They share conversation around the building with the neighbors in the vicinity. In addition, they purchase goods at retail outlets about once a week within the district and request the administration office to replace light bulbs, etc. 


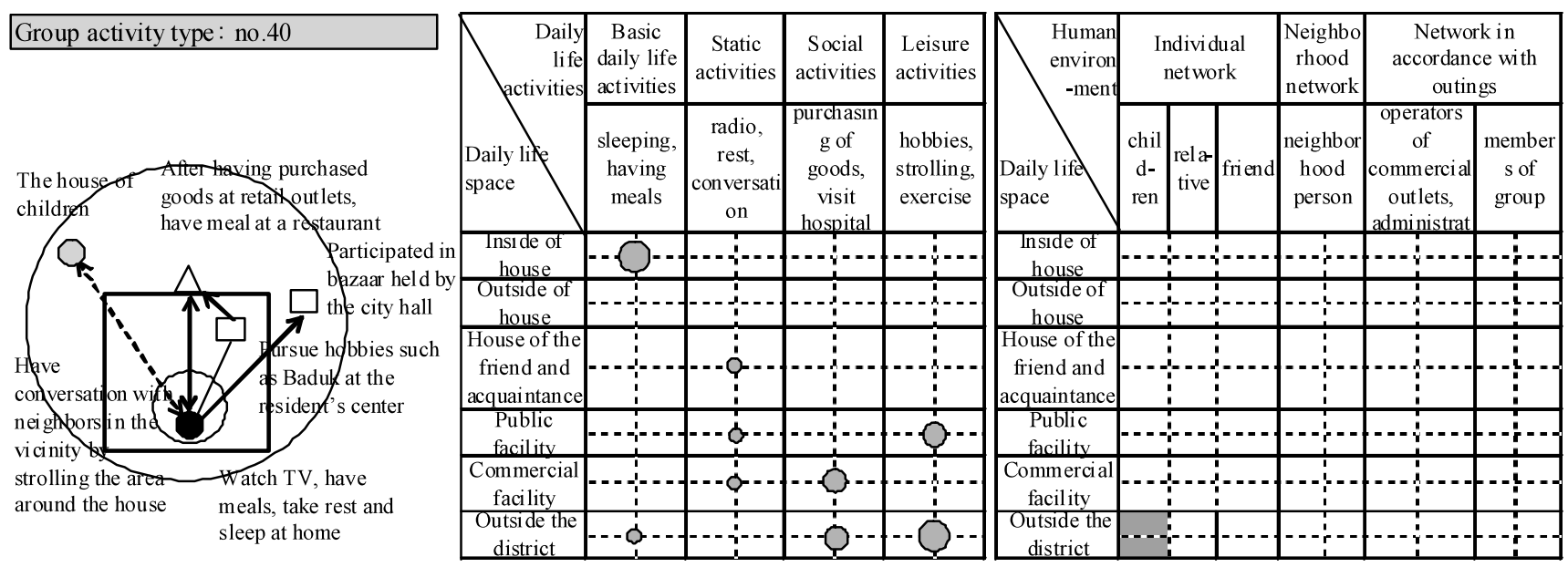

Children living separately visit the house about once a week to prepare meals. In addition, they participate in hobby activities including Baduk at the senior citizen's center within the district about once a month, and in singing class and track and field club outside the district 2 3 times a week. They also purchase goods at the retail outlets in the vicinity of the district.
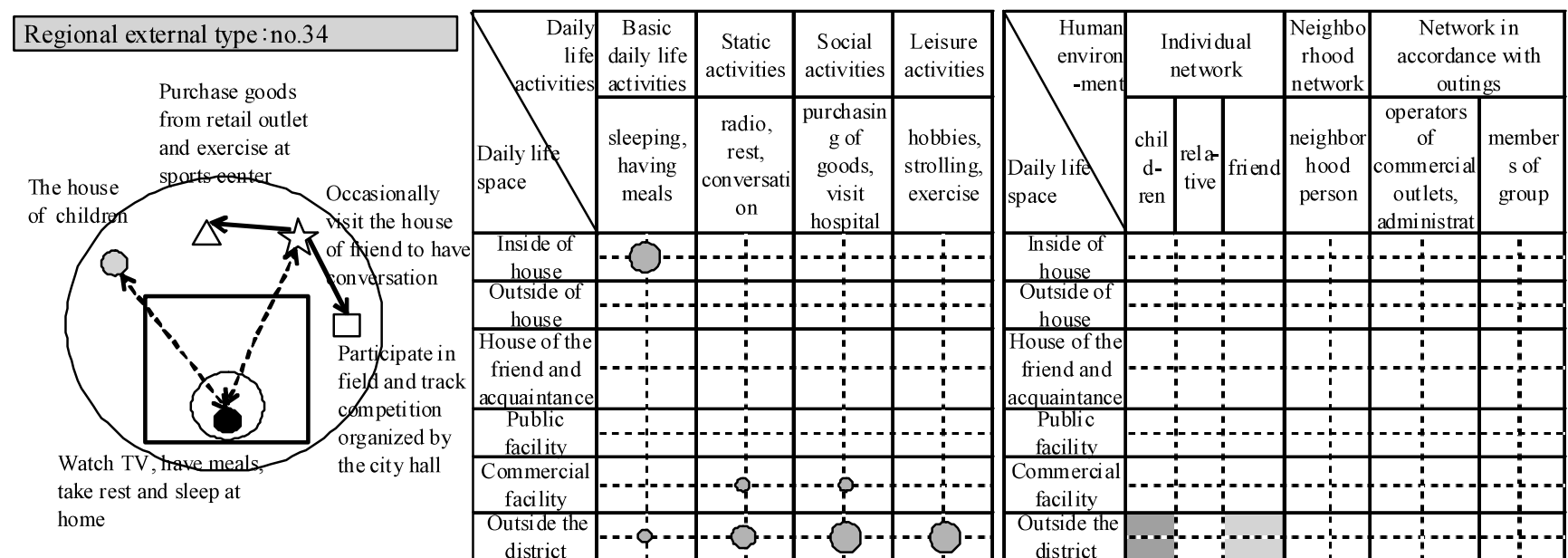

Children living separately visit the house about 2 times a week. They rarely share conversation with the neighbors in the vicinity other than greetings. They visit the house of friends residing and purchase goods in their previous residential district.
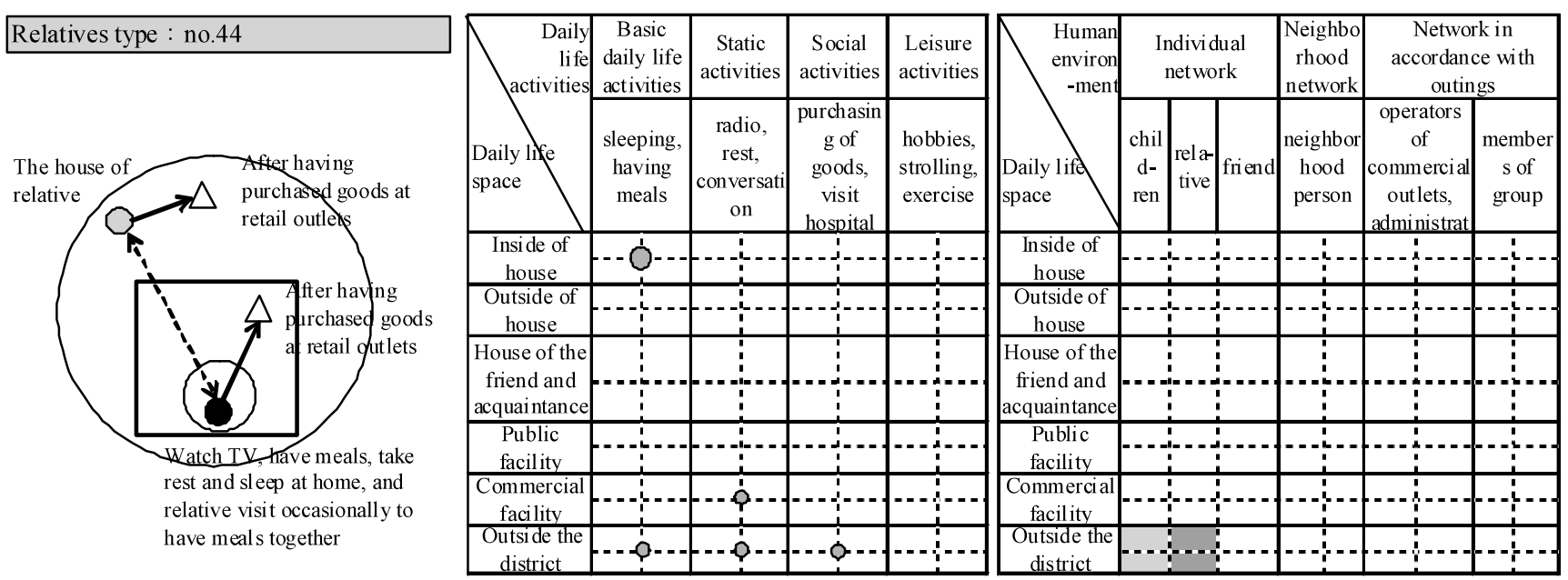

Residents living outside the district visit the house about once a week to prepare meals, purchase goods and have conversation. In addition, they use the hospital outside the district along with relatives for medical services. They do not receive support from the nei ghbors in the vicinity within the district. 

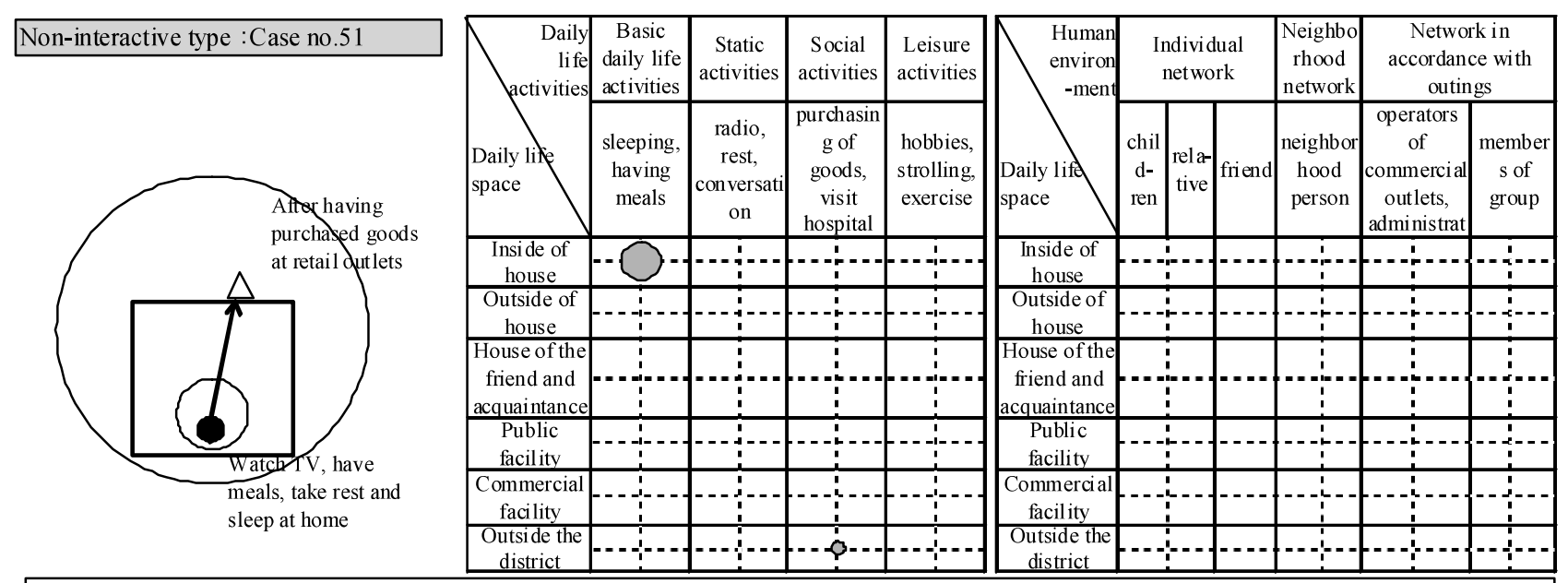

Although they have children living separately, they take care of basic daily life acti vities such as meals on their own at home. They take rest at rest and recreational facilities within the district. In addition, they purchase goods from markets and commercial facilities outside the district.

$<$ The number of times of use $\bigcirc$ : more than fifth a week $\bigcirc$ : more than twice a week $\bigcirc:$ more than once a week 0 : more than twice a month

$<$ The number of times of a visit for a safety check $>$ :

$\square$ : more than twice a week $\square$ : more than once a week $\square$ : more than twice a month

Fig.4 The Characteristics of Neighborhood Environment that Supports the Daily Life Activities of the Elderly Viewed from the Cases for Each of the Types of Residence and Interaction

within the district used for shopping are used as a venue for interaction $2 \sim 3$ times a week, and there are situations in which request for slightly awkward chores in daily life such as replacing of the light bulb are being made to the operator of the commercial facilities such as retail outlets within the district. In case 34 in the condominium complex, support only by the visits of the children living separately and friends who reside outside the district are given.

(4) Relatives type: Case 24 in the multi-family houses area, along with case 44 in the condominium complex, has scope of daily life space with the majority of basic daily life activities performed around the house. In addition, shopping at retail outlets and social activities outside the district are being done 2 3 times a month. Human support for basic daily life including preparation of meals are being provided by children and relatives living separately $2 \sim 3$ times a week, and the resident occasionally request the neighbors to purchase goods. In case 44 in the condominium complex, support necessary for basic daily life including preparations of meals are received by visiting the children and relatives living separate outside the district.

(5) Non-interactive type: Case 30 in the multi-family houses area, along with case 51 in the condominium complex, has scope of daily life space with the majority of basic daily life activities such as meals and conversations performed around the house. Other social activities and leisure activities within the district are not present. Although both cases had children living separately, both elderly persons were taking care of the basic daily life tasks including meals by themselves and they were not establishing close personal relationship within the district.

\section{Results and Considerations}

From the above, it was found that the actual state of neighborhood environment that supports the daily life activities of elderly persons in the multifamily houses area is as follows:

(1) Overall, interactions in the multi-family houses area are made mostly around one's house and quite substantial interactions are also made within the district. In contrast, interactions are made mostly outside the condominium complex. It is easy to establish open environment due to outstanding continuity and accessibility in and out of the house in the multi-family houses area, resulting in extensive interactions around the house, in comparison to those in the condominium complex. From this, it is evident that the multi-family houses area have the characteristic of offering opportunity to participate in interactions within the district for the elderly.

(2) Individual relationship type, group activity type, regional external type and relatives type interactions are prevalent in the multi-family houses area for the elderly, while there are mostly group activity type, regional external type and comparative type interactions in the condominium complex. In the case of individual relationship type and group activity type in the multi-family houses area, most of these are single person household and elderly persons in later years, and commercial facilities such as retail outlets, senior citizen's center and public facilities of the residential center were used as the base for interaction and personal exchange. This is because the domain of daily life activities gradually decreases due to the increase in age and changes in generation types and because accessibility to elements necessary in daily life of the elderly for whom the time spent within the district becomes longer, collection of information and mutual support is made easier. In addition, establishing of relationship with the local society is easier and plays important role in the midst of residing within the district by elderly persons continuously. Therefore, there is a need to maintain and activate the commercial facilities and public facilities within the district, and taxation support and implementation of system in operation is necessary in order for the existing daily life of the elderly to be maintained. 
(3) On the other hand, the possibility of being transferred to the household of their children or elderly care facilities outside the district or becoming isolated within the district is high when their scope of daily life activities becomes narrower due to further aging and physical problems for the regional external type, close relative type and non-interactive type in the multi-family houses area in comparison to other types. It is therefore deemed that establishment of daily life support system through the installation of small-scale multi-functional facilities ${ }^{\mathrm{x}}$ ) that can become the base for the local activities and create diverse range of daily life services that can establish and expand the daily life and social relationships within the district is necessary. From the above information, the characteristics of neighborhood environment, which supports the open environment from within to outside the residential units in the multi-family houses area and also supports the daily life activities of the elderly, were assessed through comparison between the features of multi-family houses area and the condominium complex. This could be an important knowledge in consolidation of the construction plan for residential units and local facilities as well as the social system in preparation of the forthcoming era of aged society in Korea.

\section{References}

1) Jo, J. H.., The theory of senior welfare. Yangseo publisher. p.114, 2009.

2) Go, J. W., The theory of senior welfare. Yangseo publisher. p.211, 2010

3) Kim, T. I., Foundation of Welfare Facilities and the Functional Intension of Community Care based on Interchange between the Multi-generation. Architecture Institute of Korea, Vol.50(11), pp.50-53, 2006.

4) Lee, S. Y., An Evaluation Outdoor Living Environments for the Elderly : User Behavior and Demand. The Korean Institute of Landscape Architecture. Vol.35(3), pp.1-12, 2007.

5) Lee, S. Y., An Evaluation Outdoor Living Environments for the Elderly : User Behavior and Demand. Journal of Welfare for the Aged, Vol.42, pp.379-406, 2008.

6) Chae,M.S., A study on Design Planning of the National Rental Apartment's Community Space Located on Ground Level Floor for Aging Society. Korea Institute of Ecological Architecture and Environment, Vol.8 (1), pp.71-79, 2008.

7) Im, B.H., A Study on the Aged's Preference of Proximity to the Supporting Facilities from their Dwellings in Daejeon Metropolitan. Korea Planners Association, Vol.46 (5), pp.113124, 2011.

Notes

i ) In this study, the neighborhood is a daily living area, which has includes human environment such as neighbors, business people and administrators that can be mutual assistance and physical environment such as commercial and public facilities.

ii ) In this Study, the community is a group that formed on the basis of the benefit and common interest in the daily life of the elderly.

iii) In this Study, local residency refers to the residential format based on the base for activities and personal support elements for which semi-formal support is possible by securing independent space within the residence of an individual on the foundation of the open space out of the residence that enables establishment and maintenance of social relationship with the district.

iv ) The ratio of rebuilding is the ratio of changes assessed through site survey on the basis of the numerical map of 1997 and 2010. The number of residential cases along with the ratio of exclusive residential unit for each of the districts was 80 cases for the land district 1 (33.1\%), 40 cases for the land district $5(13.7 \%), 107$ cases for the Suseong land district (23.3\%) and 116 cases for the Songhyeon land district $(20.0 \%)$.

v ) Conversation and greeting is behavior to spend the time with talking about a personal matters and common topic for daily life such as information of family safety, weather, shopping, health and hobby.

vi ) Urban-style Korean house have inherited the tranditional spatial properties of upper-class of the Joseon Dynasty. This house is a house for the ordinary citizens, which was built in urban areas since the 1930s.

vii) In this Study, the group refers to the gathering of people that pursues hobbies and leisure activities by belonging to the resident's center and regional clubs within the district.

viii) The senior citizen's center is a leisure and welfare facility for aged persons aimed at providing venue for pursuing hobbies and cooperative works, exchange of information and leisure activities along with seeking of friendship voluntarily by the elderly in the region in accordance with the Article 36 of the Law on Welfare for the Aged. In addition, the Article 55 of the Regulation on Standards for Construction of Residence stipulates that the floor area of the center must be more than $40 \mathrm{~m}^{2}$ including living, rest and washroom if the number of residential units in the complex is more than 100 and must satisfy the standard of $0.1 \mathrm{~m}^{2}$ for each of the residential units if there are more than 150 residential units in the complex.

ix ) Resident's center provides administrative services and programs for hobbies of the residents such as dance, calligraphy and flower arrangement in order to realize abundant life of the residents within the district on the basis of the minimum administrative unit of "dong".

x ) The small-scale multi-functional facility is a leisure and welfare facility for aged persons aimed at providing venue for pursuing hobbies and nursing care services such as day care, home help service, short-term stay, and long-term habitation for a user so that a life in the house and area to which it got used can be continued.

\section{和文要約}

韓国·多家口住宅地は個別建替えにより、高齢者の転居が多く 行われている。高齢者世帯には子世代とは同居しない単身や夫婦 のみの世帯も多く、地域内で過ごす時間が長いことから、留守番や電 球の交換などの日常の軽微な困り事、趣味活動や社会活動、休喤、 買い物などの基本的な日常生活行為が支えられる地区内の近隣施設 などの物的環境、また、友人や知人からの相互扶助、子世帯からの支 援などの人的環境からなる近隣環境が重要であると指摘されている。 多家口住宅地と周辺の集合住宅地の新規高齢者の比較を通じ、ま ず、住宅地類型別の高齢者世帯の住戸周囲の使い方と住戸周囲・ 地区内での交流特性を見ると、多家口住宅地では集合住宅地に比
べ、住戸周囲や地区内の身近にある小売店などの商業施設が高齢 者の立ち話・挨拶などの交流場所として利用されており、地区内 での交流への参加の機会を多く創出していることが分かる。また、 住宅地類型別の高齢者世帯の交流タイプ別の生活空間と人的環境 からの近隣環境の特性を見ると、多家口住宅地では集合住宅地に 比へ、「個別関係型」や「団体活動型」が多く、地区内の友人・知人 宅、小売店などの商業施設、敬人亭などの公共施設から日常生活 や団体活動に関する情報収集や参加機会を得ており、地区内での 近隣の人や環境との密接な関わりの上で生活を展開していること が分かる。 